\title{
Non-metamict betafite from Le Carcarelle (Vico volcanic complex, Italy): occurrence and crystal structure
}

\author{
F. Cámara ${ }^{1} *$, C. T. Williams ${ }^{2}$, G. Della Ventura ${ }^{3}$, R. Oberti ${ }^{1}$ and E. Caprillit ${ }^{4}$ \\ ${ }^{1}$ CNR-Istituto di Geoscienze e Georisorse, Sezione di Pavia, via Ferrata 1, I-27100 Pavia, Italy \\ 2 Department of Mineralogy, The Natural History Museum, Cromwell Road, London SW7 5BD, UK \\ ${ }^{3}$ Dipartimento di Scienze Geologiche, Università di Roma Tre, Largo S. Leonardo Murialdo 1, I-00146 Roma, Italy \\ ${ }^{4}$ Dipartimento di Scienze della Terra, Università di Modena, Largo S. Eufemia 19, I-41100 Modena, Italy
}

\section{ABSTRACT}

Non-metamict betafite, a pyrochlore-group mineral with general formula $A_{2-m} B_{2}{ }^{X} \mathrm{O}_{6}{ }^{Y}(\mathrm{O}, \mathrm{OH}, \mathrm{F})_{1-n} \cdot p \mathrm{H}_{2} \mathrm{O}$ and $2 \mathrm{Ti}>\mathrm{Nb}+\mathrm{Ta}$ and $\mathrm{U}>20 \%$ at the $A$ site, has been found at Le Carcarelle, (Latium, Italy). It occurs within miarolitic cavities of a foid-bearing syenitic ejectum enclosed within the pyroclastic formation known as "ignimbrite C", which belongs to the main effusive phase of the Vico volcanic complex. The host rock is composed of K-feldspar, biotite, augitic clinopyroxene, magnetite and minor sodalite. Electron microprobe analyses gave the following crystalchemical formula: $\left(\mathrm{Ca}_{1.24} \mathrm{Na}_{0.17} \mathrm{U}_{0.49} R E E_{0.03}\right)_{\Sigma=1.93}\left(\mathrm{Ti}_{1.05} \mathrm{Nb}_{0.76} \mathrm{Zr}_{0.14} \mathrm{Fe}_{0.04} \mathrm{Ta}_{0.01}\right)_{\Sigma=2.00} \mathrm{O}_{6}(\mathrm{O}, \mathrm{OH})$. Compared with other occurrences reported in the mineralogical literature, betafite from Le Carcarelle is extremely enriched in $U$ and depleted in Th. Due to its young age of formation $(\sim 150 \mathrm{k} . \mathrm{y}$.), this betafite sample is highly crystalline, thus allowing structure refinement of unheated material. Betafite from Le Carcarelle is cubic $F d \overline{3} m$, with $a=10.2637(13) \AA$, and $V=1081.21(35) \AA^{3}$, and has a smaller $A$ site (consistent with the higher $U$ content), and a larger and more distorted $B$ site (consistent with the higher Ti content) than calciobetafite from Campi Flegrei, Italy (Mazzi and Munno, 1983). Analysis of the atomic displacement parameters provides evidence for static disorder at the $X$ site.

KeYwords: pyrochlore, crystal structure, betafite, electron microprobe analysis, Latium, Italy.

\section{Introduction}

Pyrochlore-Group minerals are cubic oxides common as accessory minerals in carbonatites, nepheline syenites, pegmatites and granitic pegmatites. Their general formula (Hogarth, 1977; Lumpkin and Ewing, 1988) can be written as $A_{2-m} B_{2}{ }^{X} \mathrm{O}_{6}{ }^{Y}(\mathrm{O}, \mathrm{OH}, \mathrm{F})_{1-n} \cdot p \mathrm{H}_{2} \mathrm{O}$, with $A=\mathrm{Na}$, $\mathrm{K}, \mathrm{Ca}, \mathrm{Sr}, \mathrm{Sn}, \mathrm{Ba}, \mathrm{Pb}, \mathrm{Bi}, R E E, \mathrm{U}$ and $B=\mathrm{Ti}, \mathrm{Nb}$, Ta. The observed ranges of stoichiometric variations are $m=0-1.7, n=0-1.0$ and $p=$ 0-2.5 (Lumpkin and Ewing, 1988). In stoichiometric pyrochlore, charge balance is maintained by heterovalent substitutions at the $A$ and $B$ sites, possibly coupled with anionic substitutions $\left(\mathrm{O}^{2-}\right.$,

* E-mail: camara@crystal.unipv.it

DOI: $10.1180 / 0026461046860224$
$\mathrm{OH}, \mathrm{F})$ at the $Y$ site. Combinations of $A$-site cations and $Y$-site anions may however be removed to produce defect structures. An increasing content of water is generally correlated with $A$-site deficiency (Foord, 1982). Ercit et al. (1994) characterized the structure and cation ordering of a 'hydrous' kalipyrochlore, ${ }^{A}\left(\left[\mathrm{H}_{2} \mathrm{O}\right]_{0.99} \mathrm{Sr}_{0.05} \mathrm{Ca}_{0.01}\right)_{\Sigma 1.05}{ }^{B}\left(\mathrm{Nb}_{1.80}\right.$ $\left.\mathrm{Ti}_{0.20}\right)_{\Sigma 2}{ }^{X}\left(\mathrm{O}_{4.06} \mathrm{OH}_{1.94}\right)_{\Sigma 6}{ }^{Y}\left(\left[\mathrm{H}_{2} \mathrm{O}\right]_{0.86} \mathrm{~K}_{0.14}\right)$, and concluded that the amount of $\mathrm{H}_{2} \mathrm{O}$ in this structure is controlled by the $A$-site vacancies, and suggested an upper limit of $p=1.75$.

Pyrochlore minerals are classified into three subgroups on the basis of the $B$-site composition (Hogarth, 1977): pyrochlore is the Nb-dominant member, microlite is the Ta-dominant member and betafite has $2 \mathrm{Ti}>(\mathrm{Nb}+\mathrm{Ta})$. Pyrochloregroup minerals typically contain significant amounts of $R E E, \mathrm{U}$ and Th. This feature makes 


\section{F. CÁMARA ET AL.}

this structure-type one of the principal actinide host phases for nuclear waste disposal, so that it is one of the constituents of Synroc (e.g. Ringwood et al., 1988; Lumpkin et al., 1994, 2001). Mazzi and Munno (1983) reported the crystal-structure of a non-metamict calciobetafite with 4.7 wt.\% $\mathrm{UO}_{2}$ from a syenitic ejectum from Campi Flegrei (Italy), for which a geological age of $0.084 \mathrm{Ma}$ could be inferred.

The known U-rich (U > 0.4 a.p.f.u.) species in the pyrochlore group are: uranpyrochlore, uranmicrolite and betafite. Uranpyrochlore specimens have been reported from a radioactive tuff at Ndale (Uganda) (Hogarth and Horne, 1989; $\mathrm{UO}_{2}$ up to 26.4 wt.\%), from the Saima alkali complex REE-U deposit, Liaoning Province, NE China (host rock: aegirine-nepheline syenite; Wu et al., 1996), from the Kovdor, Vuoriyarvi, Seblyavr and Sallanlatvi alkali-ultrabasic massifs in Kola Peninsula, Russia (host rock: carbonatite; Belolipetskii and Voloshin, 1996), from the Lovozero alkaline complex, Kola Peninsula (host rock: agpaitic murmanite lujavrites [phonolite]; Chakhmouradian and Mitchell, 2002) and from St. Lawrence Mine, Oka, Quebec (host rock: carbonatite; Petruk and Owens, 1975). Uraniumrich microlite and uranmicrolite (containing up to 13 wt.\% $\mathrm{UO}_{2}$ ) were found in the Beauvoir peraluminous leucogranite (Massif Central, France; Ohnenstetter and Piantone, 1992), in lithium pegmatites of Mina Conco, Mozambique (Gieré et al., 1999, 2001a), and in the Yellowknife pegmatite field, Canada (Wise and Černý, 1990). Most of these samples are related to late-hydrothermal or pegmatitic alteration involving Ca-leaching.

Betafite has been reported as minute zoned inclusions in zinnwaldite in the Cínovec (Zinnwald) granite cupola (Czech Republic; analyses 4 and 5 in Johan and Johan, 1994). These specimens are significantly hydrated and altered ( $\Sigma A \approx 1$ a.p.f.u.), and their $\mathrm{Si}$ content correlates with the $\mathrm{U}$ content. Other examples of betafite include occurrences from eastern Siberia (Pozharitskaya and Samoylov, 1972; $\mathrm{UO}_{2}=$ 27.8 wt.\%), and from a hydrothermal vein system in dolomite marbles at the contact with a tonalite intrusion at Adamello, Italy (Gieré et al., $2001 b ; \mathrm{UO}_{2}=29-34$ wt.\%).

U-rich samples are commonly metamict (Lumpkin and Ewing, 1988; Finch and Murakami, 1999), and thus the details of $U$ incorporation and coordination in the ordered pyrochlore structure have not yet been clarified.
Metamictization in various pyrochlore-group minerals has been discussed by Lumpkin and Ewing (1988), who studied specimens from several localities from Madagascar and Canada, containing up to $29.8 \mathrm{UO}_{2}$ wt. $\%$ and with ages ranging from 700 to $1000 \mathrm{Ma}$. Those authors concluded that the metamictic state can be regarded as an aperiodic random network structure of corner-sharing distorted $\mathrm{BO}_{5.5}$ polyhedra. Structural analysis of these materials requires previous annealing to improve crystal quality. However, the thermal treatment may promote the oxidation state of some elements (Fe or $\mathrm{U}$ ), and so potentially alter the crystal structure and can also cause the formation of new phases (e.g. Ewing, 1975).

Pyrochlore frequently shows secondary alteration that mainly involves leaching of the $A$-site cations coupled with the incorporation of water into the structure. However, $R E E^{3+}, \mathrm{U}^{4+}$ and $\mathrm{Th}^{4+}$ are considered to be relatively immobile during alteration processes (Lumpkin and Ewing 1992; 1996; Lumpkin et al., 1999).

We describe here the occurrence of a nonmetamict sample of betafite containing 31.2 $\mathrm{UO}_{2}$ wt. $\%$ from Le Carcarelle, Vico volcanic complex, Latium, Italy. Due to its young age of formation, this sample is highly crystalline. Hence, details of the crystal-structure and cation order could be investigated on the untreated material.

\section{Occurrence}

The sample described in this study was collected at the Le Carcarelle locality, S. Martino al Cimino community (Viterbo), Vico volcanic complex, Latium, Italy. The host rock can be classified as a foid-bearing syenite (Della Ventura et al., 1999), and was sampled within the pyroclastic formation known as "C ignimbrite" (Locardi, 1965), belonging to the main effusive stage of the Vico activity. Sollevanti (1983) obtained a K/Ar age of $150 \pm 7$ k.y. for this formation, and Laurenzi and Villa (1985) obtained a similar age (151 \pm 3$)$ using the $\mathrm{Ar} / \mathrm{Ar}$ method. More recently, ages between 221 and $93 \mathrm{k} . \mathrm{y}$. were obtained using the ${ }^{230} \mathrm{Th} /{ }^{238} \mathrm{U}$ method on a suite of pyrochlore grains extracted from several ejecta in the $\mathrm{C}$ ignimbrite. Age is strongly dependent on the size of the analysed crystal, and is thus believed to represent the crystal growth interval, with the younger value representing the eruption time (Caprilli et al., unpublished data). 
Optical observations show that the ejectum is composed of intersected elongated K-feldspar with minor amphibole (magnesio-hastingsite), plagioclase, magnetite, sodalite and rare biotite. Accessory minerals, identified by means of energy-dispersive spectroscopy attached to a scanning electron microscope (SEM-EDS), include titanite, apatite and baddeleyite. Electron microscopy shows that the sodalite crystals are invariably altered to a clay-like product with secondary pyrite growing along the crystallographic planes of pre-existing sodalite (Fig. 1a). A detailed SEM-EDS study of the thin section shows the presence of very fine aggregates of an acicular REE- and (Th, U)-bearing silicophosphate mineral, close in composition to 'cheralite' (where 'cheralite' is used here for the solid-solution series in the brabantite-huttonitemonazite triangle; Bowie and Horne, 1953; Speer, 1982). Cheralite typically crystallizes on preexisting apatite, and is often associated with britholite (Fig. 1b; Oberti et al., 2001). Flakes of hellandite-group minerals (Oberti et al., 1999; Della Ventura et al., 2002) are also observed in vugs between intersecting K-feldspar crystals. Rare and very small acicular crystals of zirconolite (Bellatreccia et al., 2002) occur included within K-feldspar crystals (Fig. 1c). Additionally, a Ce-bearing mineral (we were not able to distinguish between a carbonate or oxide phase as the section was carbon-coated) fills veins and cracks across pre-existing feldspars (Fig. 1d).

Betafite occurs in miarolitic cavities as extremely rare, euhedral elongated crystals up to
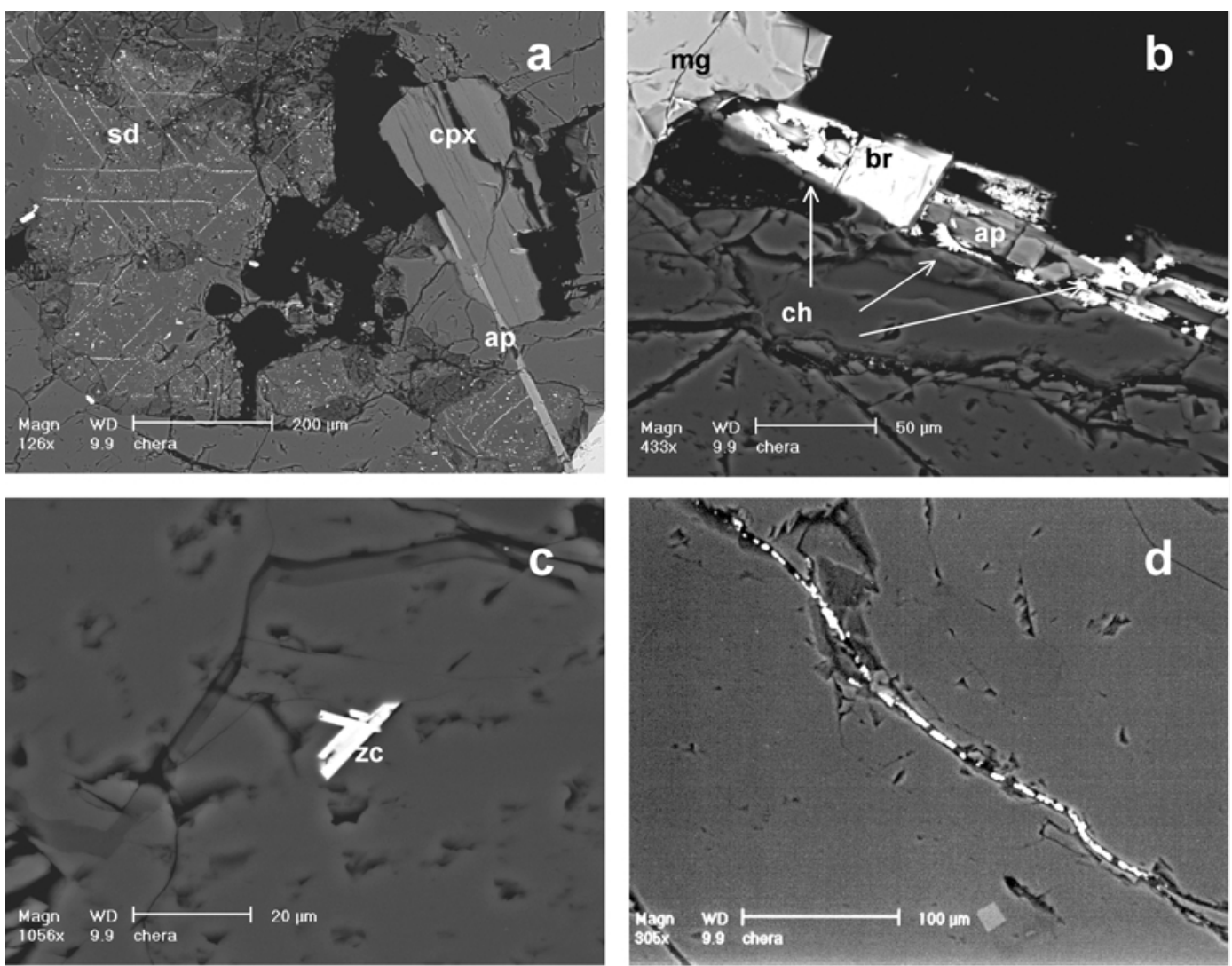

FIG. 1. SEM-BSE images showing $(a)$ altered sodalite, with small pyrite crystals aligned along crystallographic planes; (b) association of apatite (dark grey), britholite (light grey) and cheralite (acicular, light-grey crystals); (c) very small acicular zirconolite within K-feldpar; $(d)$ vein of Ce-rich phase (oxide or carbonate) + clay products across K-feldspar. $\mathrm{Cpx}=$ clinopyroxene, $\mathrm{sd}=$ sodalite, ap = apatite, $\mathrm{mg}=$ magnetite, $\mathrm{br}=\mathrm{britholite}$, $\mathrm{ch}=\mathrm{cheralite}$,

$$
\mathrm{zc}=\text { zirconolite }
$$


$100 \mu \mathrm{m}$ long and $20 \mu \mathrm{m}$ across. The crystal handpicked for X-ray and EMPA data collection was attached to a needle-like crystal (Fig. 2a) which, at higher magnification was resolved as a complex association of baddeleyite fibres intergrown with extremely fine aggregates of cheralite (Fig. 2b) and rare cubes of uraninite (Fig. 2c).

The morphology and size distribution of the cheralite needles are typical of homogeneous nucleation from a supersaturated solution (e.g. Lower et al., 1998a,b), and point to a significant circulation of mineralizing phosphate-bearing fluids enriched in REEs during very late-stage volcanic activity. These fluids were also enriched in fluorine as indicated by the presence of the thin crust of F-bearing aluminium silicate (topaz?) around the betafite crystal (Fig. 3). This scenario has already been suggested and fully documented by Della Ventura et al. (1999) and Bellatreccia et al. (2002).
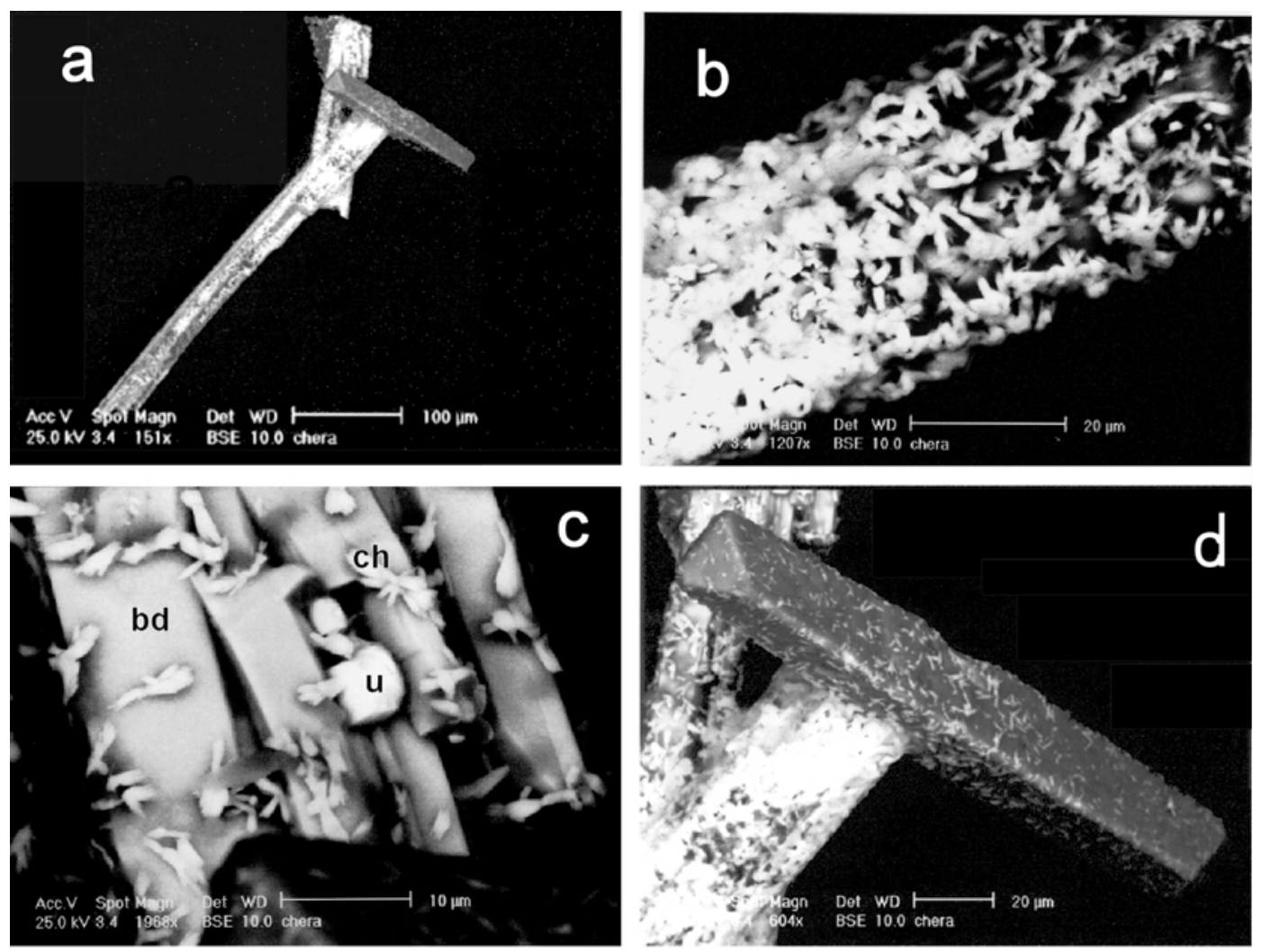

FIG. 2. SEM-BSE image of the studied crystal. (a) general view; (b) enlargement showing the cheralite crystals; (c) further enlargement showing the baddeleyite skeleton (bd) covered with cheralite (ch) and uraninite (u);

(d) detail of the betafite crystal covered with cheralite. 

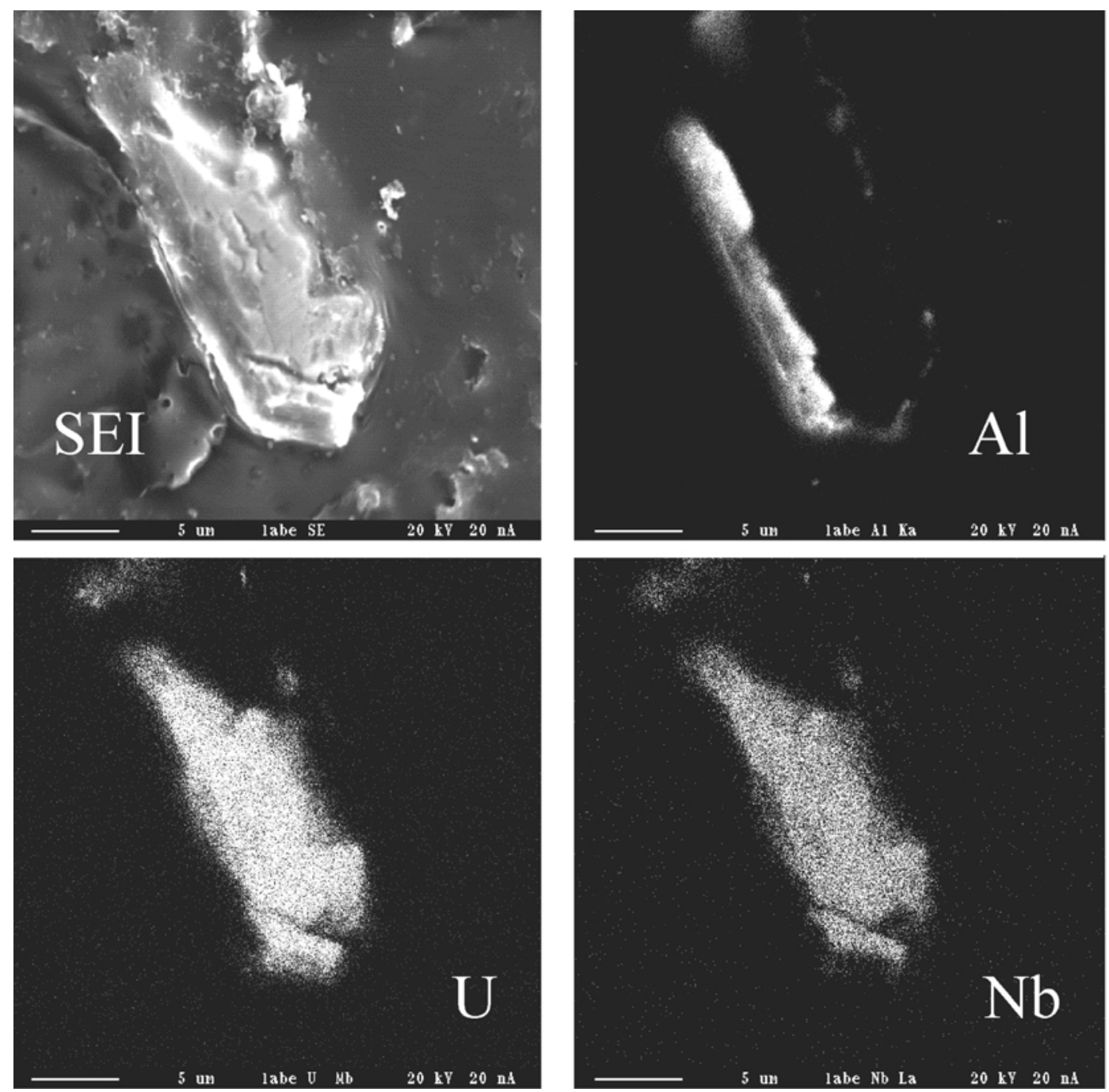

FIG. 3. X-ray maps of the studied crystal. The Al map corresponds to an overgrowth of topaz.

ejecta from Latium, both pyrochlore and zirconolite are present in the groundmass. Although zirconolite and pyrochlore are structurally (and chemically) related, paragenetic relationships between these two minerals are complex. Coexisting pyrochlore and zirconolite from a range of carbonatite complexes in the Kola Peninsula (Russia) indicate that zirconolite both crystallized later than, and in some cases replaces, early pyrochlore (e.g. Williams, 1996b), but examples are also documented where zirconolite is replaced by late-stage pyrochlore (Chakhmouradian and Williams, 2004), and the reasons for their different stability are still unclear.

\section{Experimental methods}

\section{$X$-ray diffraction}

A complete set of X-ray diffracted intensities was collected on the crystal shown in Fig. $2 a$ (size $=$ $0.20 \times 0.03 \times 0.03 \mathrm{~mm}$ ) with a Bruker-AXS SMART-APEX diffractometer working with graphite-monochromatized Mo- $K \alpha \mathrm{X}$-radiation at $50 \mathrm{kV}$ and $30 \mathrm{~mA}$; the crystal-to-detector distance was $4.0 \mathrm{~cm}$. No evidence of metamictization as peak broadening, weakening of small angle reflections or loss of $K \alpha_{1} / K \alpha_{2}$ peak splitting was found. Three dimensional data in the $\theta$ range $3-45^{\circ}$ were integrated and corrected for Lorentz, polarization and background effects using the 


\section{F. CÁMARA ET AL.}

TABLE 1. Crystal and structure refinement data for betafite from Le Carcarelle.

\begin{tabular}{ll}
\hline Wavelength & $0.71073 \AA$ \\
Crystal system & cubic \\
Space group & $F d \overline{3} m$ \\
Unit-cell dimensions & $a=10.2637(13) \AA$ \\
Volume & $1081.21(35) \AA^{3}$ \\
$Z$ & 8 \\
$F(000)$ & 1561 \\
Crystal size & $0.20 \times 0.03 \times 0.03 \mathrm{~mm}^{3}$ \\
Theta range for data collection & 3.44 to $44.93^{\circ}{ }^{3}$ \\
Index ranges & $-15 \leqslant h \leqslant 10,-10 \leqslant k \leqslant 8,-20 \leqslant l \leqslant 10$ \\
Reflections collected & 760 \\
Independent reflections & $246[R($ int $)=1.4 \%]$ \\
Completeness to $\theta=44.93^{\circ}$ & $98.4 \%$ \\
Density calculated & $5.304 \mathrm{mg} / \mathrm{m}^{3}$ \\
Absorption coefficient & $19.261 \mathrm{~mm}{ }^{-1}$ \\
Refinement method & Full-matrix least-squares on $F^{2}$ \\
Data/restraints/parameters & $246 / 2 / 17$ \\
Goodness-of-fit on $F^{2}$ & 1.298 \\
Final $R$ indices $[I>2 \sigma(I)]$ & $R 1=5.0^{2} \%$, w $R 2=14.2 \%$ \\
Final $R$ indices (all data) & $R 1=5.9^{2} \%$, w $R 2=14.8 \%$ \\
Extinction coefficient & $0.0006(2)$ \\
Largest diffraction peak and hole & 1.457 and -0.973 e $\AA^{-3}$ \\
& \\
\hline
\end{tabular}

SAINT+ software version 6.02 ( $(\mathrm{R})$ Bruker AXS). Raw intensities were corrected for absorption using the SADABS v. 2.03 program (Sheldrick, 1996), and then merged yielding $R$ (int) $=1.4 \%$. Unit-cell dimensions were calculated from leastsquares refinement of the positions of all the collected reflections.

Betafite from Le Carcarelle is cubic $F d \overline{3} m$, with edge $=10.2637(13) \AA$, and $V=1081.21(35) \AA^{3}$. A weighted full-matrix least-squares refinement on $F^{2}$ was done using SHELXTL (Sheldrick, 1997) starting from the coordinates of Mazzi and Munno (1983), and yielded $w R 2=14.8 \%, R 1=$ $5.9 \%$ for all the independent reflections. Table 1 reports selected crystal and refinement data;
Table 2 lists atom coordinates, displacement parameters, and refined site-scattering values (ss, e.p.f.u.); Table 3 lists the geometric parameters relevant to the description of the crystal structure; Table 4, available from the Principal Editor, or from the Mineralogical Society website WWW.minersoc.org/pages/e journals/dep_met.htm, lists observed and calculated structure factors.

\section{EMPA and SEM analysis}

Electron microprobe analyses (EMPA) were performed at The Natural History Museum, London, with a Cameca SX50 wavelengthdispersive electron microprobe, operated at

TABLE 2. Atomic coordinates, equivalent isotropic displacement parameters $\left(\AA^{2} \times 10^{3}\right)$, and anisotropic displacement parameters $\left(\AA^{2} \times 10^{3}\right)$ for betafite from Le Carcarelle. The anisotropic displacement factor has the form: $-2 \pi^{2}\left[h^{2} a^{* 2} U_{11}+\ldots+2 h k a^{*} b^{*} U_{12}\right]$. $U_{(\mathrm{eq})}$ is defined as one third of the trace of the orthogonalized $U_{i j}$ tensor.

\begin{tabular}{|c|c|c|c|c|c|c|c|c|c|c|c|}
\hline Site & ss* & $x / a$ & $y / b$ & $z / c$ & $U_{(\mathrm{eq})}$ & $U_{11}$ & $U_{22}$ & $U_{33}$ & $U_{23}$ & $U_{13}$ & $U_{12}$ \\
\hline$A$ & $74.1(5)$ & 0 & 0 & 0 & $9(1)$ & $9(1)$ & $9(1)$ & $9(1)$ & $-2(1)$ & $-2(1)$ & $-2(1)$ \\
\hline$B$ & $65.3(1)$ & $1 / 2$ & $1 / 2$ & $1 / 2$ & $12(1)$ & $12(1)$ & $12(1)$ & $12(1)$ & $-1(1)$ & $-1(1)$ & $-1(1)$ \\
\hline$X$ & 48 & $0.8252(5)$ & $1 / 8$ & $1 / 8$ & $14(1)$ & $19(2)$ & $11(1)$ & $11(1)$ & $6(1)$ & 0 & 0 \\
\hline Y & $7.6(3)$ & $1 / 8$ & $1 / 8$ & $1 / 8$ & $26(3)$ & $26(4)$ & $26(4)$ & $26(4)$ & 0 & 0 & 0 \\
\hline
\end{tabular}

\footnotetext{
* ss: site scattering in electrons per formula unit (e.p.f.u.)
} 
TABLE 3. Bond lengths $(\AA)$ and angles $\left(^{\circ}\right)$ for betafite from Le Carcarelle and calciobetafite from Campi Flegrei (Mazzi and Munno, 1983).

\begin{tabular}{lcc}
\hline & Le Carcarelle & Campi Flegrei \\
\hline$A-Y \times 2$ & 2.2222 & 2.2295 \\
$A-X \times 6$ & $2.552(3)$ & $2.577(3)$ \\
$<A-X, Y>$ & 2.467 & 2.490 \\
$V\left(\AA^{\circ}\right)$ & 24.30 & 24.92 \\
$B-X \times 6$ & $1.972(2)$ & $1.969(3)$ \\
$V\left(\AA^{3}\right)$ & 10.10 & 10.10 \\
$\mathrm{OA}^{*}$ & 26.53 & 18.14 \\
$\mathrm{OQE}^{*}$ & 1.0079 & 1.0054 \\
$A-X-A$ & $90.64(16)$ & 89.90 \\
$B-X-B$ & $133.9(3)$ & 135.2 \\
$A-X-B$ & $105.97(7)$ & 105.65 \\
$A-Y-A$ & 109.47 & 109.47 \\
$A-A$ & 3.6288 & 3.641 \\
& & \\
\hline
\end{tabular}

* Robinson et al. (1971)

$20 \mathrm{kV}$ accelerating voltage and $20 \mathrm{nA}$ beam current. Standards used were a combination of well-characterized natural minerals, synthetic compounds and pure metals. Background positions, particularly for the REE, were carefully selected to avoid contributions from potentially interfering lines, and corrections were made for interfering elements following the procedure given in Williams $(1996 a)$. Element distribution

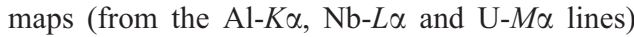
were also obtained on the Cameca SX50 electron microprobe operated at $20 \mathrm{kV}$ and $20 \mathrm{nA}$. Backscattered electron (BSE) images and energydispersive analyses were obtained at LIME (Laboratorio Interdipartimentale di Microscopia Elettronica, Università di Roma Tre) using a high resolution Philips XL30 analytical scanning electron microscope (SEM) equipped with a super UTW nitrogen-cooled EDAX detector.

\section{Results and discussion}

The EMPA results show that the specimen from Le Carcarelle is almost stoichiometric and relatively homogeneous in composition, as indicated by the low standard deviations for all oxides and low values obtained using Boyd's homogeneity index (Boyd et al., 1967), Table 5. The major components have Boyd index values $<3$ (with the exception of $\mathrm{Ti}=3.3$ ) and indicate the sample is homogeneous for these elements. Boyd's homogeneity index is generally less reliable for minor components where instrumental and counting errors become more significant at low concentrations, and a value of 4 has been suggested by Potts et al. (1983) as being a more realistic value.

Due to the possibility of $A$-site vacancies, the unit formula of pyrochlore-group minerals is conventionally normalized to $2 B$ cations per formula unit (p.f.u.). This procedure yields a total of $1.94 A$-site cations, and the total positive charge calculated on this basis is 13.45 , which suggests some $\mathrm{OH}$ at the $Y$ site. However, bondvalence calculations (see the following section) discard the presence of significant structural $\mathrm{OH}$ in the crystal studied, and normalization on the basis of 7 anions p.f.u. yields cation sums close to 2 a.p.f.u. in both the $A$ and $B$ sites. The resulting crystal-chemical formula is: ${ }^{A}\left(\mathrm{Ca}_{1.29} \mathrm{Na}_{0.18}\right.$ $\left.\mathrm{U}_{0.50}^{4+} R E E_{0.03}\right)_{\Sigma 2.00}{ }^{B}\left(\mathrm{Ti}_{1.09} \mathrm{Nb}_{0.79} \mathrm{Zr}_{0.14}\right.$ $\left.\mathrm{Fe}_{0.04}^{3+} \mathrm{Ta}_{0.01}\right)_{\Sigma 2.07} \mathrm{O}_{6}{ }^{Y}\left(\mathrm{O}_{0.98} \mathrm{~F}_{0.02}\right)$. This formula matches the ideal $A_{2} B_{2} \mathrm{O}_{7}$ stoichiometry, and thus indicates the absence of secondary alteration.

The $\mathrm{Zr}$ concentration is relatively high $\left(\mathrm{ZrO}_{2}=\right.$ 4.03 wt.\%, Table 5). Incorporation of $\mathrm{Zr}^{4+}$, an ion of intermediate size, is known in natural pyrochlore, particularly those from carbonatites (e.g. Hogarth, 1989), where $\mathrm{Zr}^{4+}$ is assigned to the $B$ site in accordance with synthetic REE-Zr pyrochlores (Hayakawa and Kamizono, 1993; Subramanian et al., 1983). Concentrations of $\mathrm{ZrO}_{2}$ as high as $\sim 10 \mathrm{wt} . \%$ have been reported for pyrochlore from the Cape Verde Islands (Hodgson and Le Bas, 1992).

The X-ray maps reported in Fig. 3 show that U (31.19 wt.\%) and $\mathrm{Nb}$ (24.32 wt.\%) are homogeneously incorporated in the structure, and that the betafite crystal of this work is enclosed by a thin crust of a F-bearing aluminium silicate (probably topaz).

The pyrochlore structure was first refined by Gaertner (1930), who noted that it basically derives from that of fluorite, and the crystalchemistry was reviewed by Chakoumakos (1984). The 'normal' pyrochlore structure can be described as a framework of corner-sharing octahedra ( $B$ sites) occupied by $\mathrm{Ti}, \mathrm{Nb}, \mathrm{Ta}$. The $A$ site is eight-fold coordinated (distorted cube close to a trigonal scalenohedron), and is occupied by alkalis, alkaline earths and actinides. In the 'inverse' pyrochlore structure the $A$ site is vacant, and the alkaline cations occupy the $Y$ site. This latter arrangement is preferred by the large alkaline cations $(\mathrm{K}, \mathrm{Rb}, \mathrm{Cs})$. A mixed inversenormal' pyrochlore structure has been described 


\section{F. CÁMARA ET AL.}

TABLE 5. Electron microprobe analysis (mean and standard deviation of 10 points) of the betafite crystal used for the structure refinement. Unit formulae normalized to: (a) 7 anions and (b) $\Sigma B=2$ (see text). Elements $<0.005$ a.p.f.u. are not reported in the formula.

\begin{tabular}{|c|c|c|c|c|c|c|c|c|}
\hline \multirow{3}{*}{$\begin{array}{l}\text { Oxides } \\
\mathrm{SiO}_{2} \\
\mathrm{P}_{2} \mathrm{O}_{5}\end{array}$} & \multirow[t]{2}{*}{ mean } & \multirow{2}{*}{$\begin{array}{l}\text { s.d. } \\
\text { b.d.l. }{ }^{\dagger}\end{array}$} & \multirow{2}{*}{$\frac{\text { BOYD* }}{-}$} & \multirow[t]{2}{*}{ a.p.f.u. } & \multicolumn{2}{|c|}{$a$} & \multicolumn{2}{|c|}{$b$} \\
\hline & & & & & mean & s.d. & mean & s.d. \\
\hline & & b.d.l. & - & $\mathrm{La}^{3+}$ & 0.01 & 0.00 & 0.01 & 0.00 \\
\hline $\mathrm{Al}_{2} \mathrm{O}_{3}$ & 0.05 & 0.02 & 2.79 & $\mathrm{Ce}^{3+}$ & 0.02 & 0.00 & 0.02 & 0.00 \\
\hline $\mathrm{TiO}_{2}$ & 20.23 & 0.34 & 3.31 & $\mathrm{Th}^{4+}$ & 0.01 & 0.00 & 0.01 & 0.00 \\
\hline $\mathrm{Fe}_{2} \mathrm{O}_{3}$ & 0.75 & 0.10 & 3.12 & $\mathrm{U}^{4+}$ & 0.50 & 0.01 & 0.48 & 0.01 \\
\hline $\mathrm{MgO}$ & & b.d.1. & - & $\mathrm{Mn}^{2+}$ & 0.01 & 0.00 & 0.01 & 0.00 \\
\hline $\mathrm{MnO}$ & 0.21 & 0.06 & 4.56 & $\mathrm{Na}^{+}$ & 0.18 & 0.02 & 0.17 & 0.01 \\
\hline $\mathrm{CaO}$ & 16.69 & 0.20 & 2.10 & $\mathrm{Ca}^{2+}$ & 1.29 & 0.01 & 1.24 & 0.02 \\
\hline $\mathrm{SrO}$ & & b.d.1. & - & $\sum A$ & 2.02 & 0.02 & 1.94 & 0.03 \\
\hline $\mathrm{BaO}$ & & b.d.1. & - & & & & & \\
\hline $\mathrm{Na}_{2} \mathrm{O}$ & 1.26 & 0.13 & 2.81 & $\mathrm{Nb}^{5+}$ & 0.79 & 0.02 & 0.76 & 0.02 \\
\hline $\mathrm{K}_{2} \mathrm{O}$ & & b.d.1. & - & $\mathrm{Ta}^{5+}$ & 0.01 & 0.00 & 0.01 & 0.00 \\
\hline $\mathrm{Nb}_{2} \mathrm{O}_{5}$ & 24.32 & 0.77 & 3.00 & $\mathrm{Ti}^{4+}$ & 1.09 & 0.02 & 1.05 & 0.02 \\
\hline $\mathrm{Ta}_{2} \mathrm{O}_{5}$ & 0.54 & 0.11 & 3.55 & $\mathrm{Fe}^{3+}$ & 0.04 & 0.01 & 0.04 & 0.01 \\
\hline $\mathrm{La}_{2} \mathrm{O}_{3}$ & 0.22 & 0.04 & 3.76 & $\mathrm{Zr}^{4+}$ & 0.14 & 0.00 & 0.14 & 0.00 \\
\hline $\mathrm{Ce}_{2} \mathrm{O}_{3}$ & 0.68 & 0.07 & 2.64 & $\Sigma B$ & 2.07 & 0.01 & 2.00 & 0.00 \\
\hline $\mathrm{Nd}_{2} \mathrm{O}_{3}$ & & b.d.1. & - & & & & & \\
\hline $\mathrm{Sm}_{2} \mathrm{O}_{3}$ & & b.d.1. & - & $\mathrm{O}$ & 6.98 & 0.02 & 6.72 & 0.03 \\
\hline $\mathrm{ZrO}_{2}$ & 4.03 & 0.15 & 1.40 & F & 0.02 & 0.02 & 0.02 & 0.02 \\
\hline $\mathrm{ThO}_{2}$ & 0.60 & 0.08 & 1.76 & & & & & \\
\hline $\mathrm{UO}_{2}$ & 31.19 & 0.56 & 2.55 & $\operatorname{ss} A^{* *}$ & 76.66 & 0.66 & 73.71 & 0.47 \\
\hline $\mathrm{Y}_{2} \mathrm{O}_{3}$ & 0.11 & 0.06 & 4.43 & $\operatorname{ss} B^{* *}$ & 63.74 & 0.70 & 61.63 & 0.97 \\
\hline $\mathrm{F}$ & 0.08 & 0.10 & - & & & & & \\
\hline Total & 101.02 & 1.16 & & Ch. $A^{\S}$ & 4.91 & 0.04 & 4.72 & 0.06 \\
\hline $\mathrm{O}=\mathrm{F}$ & 0.03 & 0.04 & & Ch. $B$ & 9.04 & 0.06 & 8.73 & 0.02 \\
\hline Total & 100.99 & 1.18 & & $\Sigma$ Ch. & 13.95 & 0.03 & 13.45 & 0.05 \\
\hline
\end{tabular}

in cesstibtantite and kalipyrochlore (Ercit et al., 1993, 1994).

Table 3 compares the geometrical parameters refined for betafite from Le Carcarelle with those refined for calciobetafite from Campi Flegrei by Mazzi and Munno (1983) $\left[{ }^{A}\left(\mathrm{Ca}_{1.26} \mathrm{Na}_{0.24} R E E_{0.19}\right.\right.$ $\left.\mathrm{Fe}_{0.12}^{2+} \mathrm{Th}_{0.08} \mathrm{U}_{0.08}\right)_{\Sigma=1.97}{ }^{B}\left(\mathrm{Ti}_{0.83} \mathrm{Nb}_{1.09} \mathrm{Ta}_{0.05}\right.$ $\left.\mathrm{Zr}_{0.03}\right)_{\Sigma=2.00}$. The two structures are broadly similar. The longer $B-X$ distance in betafite is consistent with the different aggregate ionic radius calculated from the site population, and the stronger octahedral distortion is consistent with its higher $\mathrm{Ti}^{4+}$ content. Additionally, the smaller $\langle A-X, Y\rangle$ distance is consistent with the higher $\mathrm{U}$ content.
Among the four sites available in the pyrochlore structure, the $A$ site has the smallest atomic displacement parameter (adp) in both samples. Whereas the equivalent isotropic adp values at the $B$ site are equal in the two specimens, the adp value at the $A$ site is lower in betafite (0.0088 vs. $\left.0.0097 \AA^{2}\right)$, and those at the $X$ and $Y$ sites are higher $\left(X: 0.0135\right.$ vs. $0.0110 \AA^{2} ; Y: 0.0263$ vs. $0.0223 \AA^{2}$ ). This latter feature may be due to the different local (short-range) arrangements of the anion. For instance, the anion at the $X$ site may coordinate either: (1) two $R^{5+}$ at the $B$ site and two $R^{2+}$ at the $A$ site, or (2) two $R^{4+}$ at the $B$ site, one $R^{4+}$ and one $R^{2+}$ at the $A$ site. Given the different ionic radii of the relevant cations, a 
certain degree of static disorder is expected for the anion, which can be expressed by higher adp values in the long-range perspective. Actually, Fig. 4 shows that the larger adp component of the $X$ site lies on the plane containing the $A-X-A$ angle, allowing for different $X$ positions along the $A-X$ bonds.

In the pyrochlore structure, the only atom coordinate not fixed by symmetry is the $x$ coordinate of the $X$ site (48f). In this work, we used the setting proposed by Mazzi and Munno (1983) for calciobetafite from Campi Flegrei. In the setting used by Chakoumakos (1984), $x$ is equal to 0.4248(5) for betafite from Le Carcarelle and to 0.4271(4) for calciobetafite from Campi Flegrei; both these values cluster around $0.422(10)$ as observed by Chakoumakos (1984) and explained by the requirement of maximum anion separation. The deformation parameter OAV (octahedral angle variance; Robinson et al., 1971) is larger in betafite from Le Carcarelle $\left(26.53^{\circ}\right.$, Table 3$)$ than in calciobetafite from Campi Flegrei $\left(18.14^{\circ}\right.$; Mazzi and Munno, 1983). This observation is consistent with the occurrence of a regular $B$ octahedron at an $x$ value of 0.4375 . The $x$ value calculated based on ionic radii (Shannon, 1976; cf. equation 2 in Chakoumakos, 1984) is 0.42 , namely 0.005 lower than the observed value. This behaviour is consistent with the discussion of Chakoumakos (1984), and confirms the intrinsic relaxation of the pyrochlore structure.

Betafite from Le Carcarelle with $\mathrm{UO}_{2}=31.19 \%$ (Table 5) contains the highest reported concentra- tion of $U$ in a non-metamict pyrochlore-group mineral. An occurrence of W-,Ti-rich pyrochlore described by Lumpkin et al. (1999) in $40 \mathrm{Ma}$ hydrothermal vein samples from Adamello, Italy contains 29-34 wt.\% $\mathrm{UO}_{2}$ but, although not characterized structurally, is likely to be partially metamict. In the specimen studied in this work, calculation of the alpha decay dose $(D)$ and displacements per atom ( $d p a)$ using equation (1) in Lumpkin and Ewing (1988) gives $D=$ $0.013 \times 10^{16}$ alpha-events $/ \mathrm{mg}$ and $0.02 \mathrm{dpa}$. Lumpkin (pers. comm.) suggested that this calculated dose is well below the onset of observable damage using standard X-ray diffraction in natural pyrochlore samples $(D \approx$ $0.05-0.1 \times 10^{16}$ alpha-events $/ \mathrm{mg}$ or $\sim 0.06-0.12 d p a$ ), and even below the typical onset of damage in pyrochlore doped with ${ }^{238} \mathrm{Pu}$ or ${ }^{244} \mathrm{Cm}$. Non-metamict uranoan pyrochlore and uranpyrochlore specimens, with $\mathrm{UO}_{2}$ up to $26.4 \mathrm{wt} . \%$, have been so far described only in a radioactive tuff at Ndale, Uganda (Hogarth and Horne, 1989), where the crystalline nature was also attributed to the very young geological age (4-5 k.y.). However, only the unit-cell edge is reported for these specimens. The unit-cell volume of uranpyrochlore from Ndale $\left[V=1103.3(4) \AA^{3}\right]$ is larger than that of betafite from Le Carcarelle $[V$ $\left.=1081.2(4) \AA^{3}\right]$, in agreement with the compositional differences (higher $\mathrm{Na}, \mathrm{Ca}, \mathrm{Nb}$ and $\mathrm{Ta}$, and lower $\mathrm{U}$ and $\mathrm{Ti}$ ). It is worth noting that the strong compositional homogeneity observed for the crystals from both these localities imply chemical equilibrium with the fluid during crystallization.

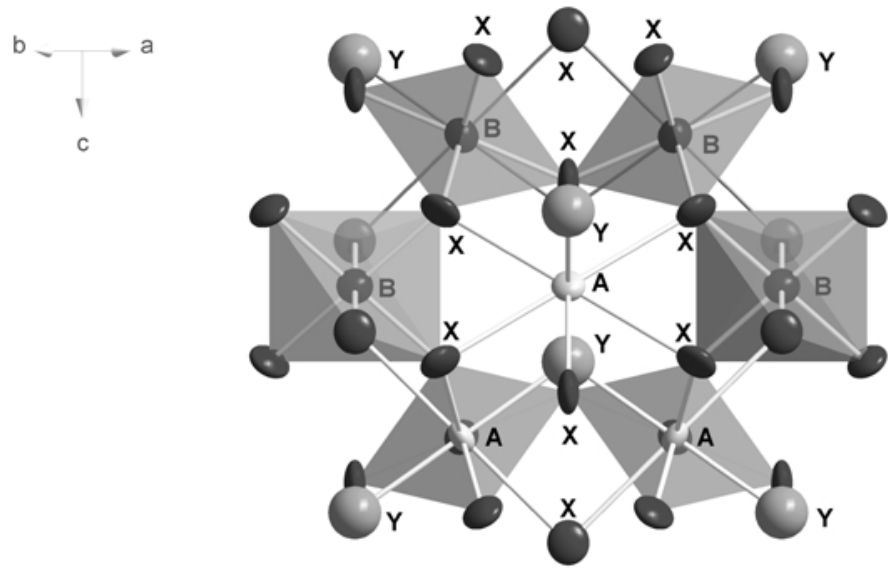

FIG. 4. The [1 110$]$ projection of the structure of betafite from Le Carcarelle. Thermal ellipsoids are plotted at $95 \%$ probability. The adp ellipsoid at the $X$ site is elongated along the line bisecting the $A-X-A$ angle, which suggests the presence of cations with very different ionic radii at the $A$ site. 


\section{F. CÁMARA ET AL.}

\section{Composition at the anion sites}

Bond valence calculations were performed using the simplified composition $\left(\mathrm{Ca}_{1.5} \mathrm{U}_{0.5}\right)_{\Sigma=2.0}$ $\left(\mathrm{Ti}_{1.0} \mathrm{Nb}_{1.0}\right)_{\Sigma=2.00}$, and yielded bond-valence sums of 1.94 and 2.20 valence units (v.u.) at the $X$ and $Y$ sites, respectively. Calculations were done using the software Valist 1.0 (Wills and Brown, 1999) and the parameters listed in Brown and Altermatt (1985). The results exclude the presence of structural $\mathrm{OH}$, and also explain the negligible F content. Actually, the betafite structure is not expected to host significant amounts of $\mathrm{OH}$ or $\mathrm{F}$ at the $Y$ site. In fact, local bond-valence considerations indicate that the substitution vector ${ }^{A}\left(\mathrm{Na}_{1} \mathrm{Ca}_{-1}\right)^{Y}\left[(\mathrm{OH}, \mathrm{F})_{1} \mathrm{O}_{-1}^{2}\right]$ applies only when an $R^{5+}$ cation is present at the $B$ site.

\section{Acknowledgements}

Greg Lumpkin kindly calculated the cumulated alpha-dose and $d p a$ values in our sample; $\mathrm{T}$. Geisler-Wierwille provided useful suggestions which improved the quality of the manuscript. We gratefully acknowledge their contributions. Financial support by Istituto Nazionale per la Ricerca Scientifica e Tecnologica sulla Montagna (INRM) to GDV is acknowledged.

\section{References}

Bellatreccia, F., Della Ventura, G., Williams, C.T., Lumpkin, G.R., Smith, K.L. and Colella, M. (2002) Non-metamict zirconolite polytypes from the feldspathoid-bearing alkali-syenitic ejecta of the Vico volcanic complex (Latium, Italy). European Journal of Mineralogy, 14, 809-820.

Belolipetskii, A.P. and Voloshin, A.V. (1996) Yttrium and rare earth element minerals of the Kola Peninsula, Russia. Pp. 311-326 in: Rare Earth minerals. Chemistry, Origin and Ore Deposits (A.P. Jones, F. Wall and C.T. Williams, editors). The Mineralogical Society Series, 7. Chapman \& Hall, London.

Bowie, S.H.U. and Horne, J.E.T. (1953) Cheralite, a new mineral of the monazite group. Mineralogical Magazine, 30, 93-99.

Boyd, F.R., Finger, L.W. and Chayes, F. (1967) Computer reduction of electron probe data. Carnegie Institution of Washington Yearbook, 67, $21-215$.

Brown, I.D. and Altermatt, D. (1985) Bond-valence parameters obtained from a systematic analysis of the inorganic crystal structure database. Acta
Crystallographica, B41, 244-247.

Caprilli, E., Della Ventura, G., Williams, C.T., Parodi, G.C. and Tuccimei, P. (2005) Crystal chemistry of non-metamict pyrochlore group minerals from Latium (Italy). The Canadian Mineralogist (submitted).

Chakhmouradian, A.R. and Mitchell, R.H. (2002) New data on pyrochlore- and perovskite-group minerals from the Lovozero alkaline complex, Russia. European Journal of Mineralogy, 14, 821-836.

Chakhmouradian, A.R. and Williams, C.T. (2004) Mineralogy of high-field-strength elements ( $\mathrm{Ti}, \mathrm{Nb}$, $\mathrm{Zr}$, Ta, Hf) in phoscoritic and carbonatitic rocks of the Kola Peninsula, Russia. Pp. 293-340 in: Phoscorites and Carbonatites from Mantle to Mine: the Key Example of the Kola Alkaline Province (F. Wall and A. Zeitsev, editors). Mineralogical Society Series 10, Mineralogical Society, London.

Chakoumakos, B.C. (1984) Systematics of the pyrochlore structure type, ideal $\mathrm{A}_{2} \mathrm{~B}_{2} \mathrm{X}_{6} \mathrm{Y}$. Journal of Solid State Chemistry, 53, 120-129.

Della Ventura, G., Williams, C.T., Cabella, R., Oberti, R., Caprilli, E. and Bellatreccia, F. (1999) Britholitehellandite intergrowths and associated REE minerals from the alkali-sienitic ejecta of the Vico volcanic complex (Latium, Italy); petrological implications bearing on REE mobility in volcanic systems. European Journal of Mineralogy, 11, 843-854.

Della Ventura, G., Bonazzi, P., Oberti, R. and Ottolini, L. (2002) Ciprianiite and mottanaite-(Ce), two new minerals of the hellandite group from Latium (Italy). American Mineralogist, 87, 739-744.

Ercit, T.S., Černý, P. and Hawthorne, F.C. (1993) Cesstibtantite - a geologic introduction to the inverse pyrochlores. Mineralogy and Petrology, 48, $235-255$.

Ercit, T.S., Hawthorne, F.C. and Černý, P. (1994) The structural chemistry of kalipyrochlore, a 'hydropyrochlore'. The Canadian Mineralogist, 32, 415-420.

Ewing, R.C. (1975) Alteration of metamict, rare-earth, $\mathrm{AB}_{2} \mathrm{O}_{6}$-type $\mathrm{Nb}$-Ta-Ti oxides. Geochimica et Cosmochimica Acta, 39, 521-530.

Foord, E.E. (1982) Minerals of tin, titanium, niobioum and tantalum in granitic pegmatites. Pp. 187-238 in Granitic pegmatites in Science and Industry ( $\mathrm{P}$. Černý, editor). Short-Course Handbook, 8 . Mineralogical Association of Canada, Toronto, Ontario, Canada.

Finch, R. and Murakami, T. (1999) Systematics and paragenesis of Uranium minerals. Pp. 91-179 in Uranium: Mineralogy, Geochemistry and the Environment (P.C. Burns and R. Finch, editors). Reviews in Mineralogy, 38. Mineralogical Society of America, Washington, D.C.

[Gaertner, H.R. von (1930) Die Kristallstrukturen von 
Loparit und Pyrochlor. Neues Jahrbuch für Mineralogie und Beilage-Band 61 Abt A, 1-30] cited in Gieré, R., Buck, E.C., Guggenheim, R., Mathys, D. and Reusser, E. (1999) Alteration of uranium-rich microlite from Mozambique. Abstract with Programs - Geological Society of America, 31, 135.

Gieré, R., Buck, E.C., Guggenheim, R., Mathys, D. and Reusser, E. (1999) Alteration of uranium-rich microlite from Mozambique. Abstract with Programs - Geological Society of America, 31, 135.

Gieré, R., Buck, E.C., Guggenheim, R., Mathys, D., Reusser, E. and Marques, J. (2001a) Alteration of uranium-rich microlite. Pp. 935-944 in Scientific Basis for Nuclear Waste Management XXIV (K.P. Hart and G.R. Lumpkin, editors). Materials Research Society Symposium Proceedings, Warrendale Publishers, Pennsylvania: Vol. 663.

Gieré, R., Lumpkin, G.R., Williams, C.T., Smith, K.L., Payne, T.E., McGlinn, P.J., Hart, K.P. and Oberti, F. (2001b) Geochemistry of hydrothermal veins containing zirconolite and betafite at Adamello, Italy. Pp. 979-987 in: Scientific Basis for Nuclear Waste Management XXIV (K.P. Hart and G.R. Lumpkin, editors). Materials Research Society Symposium Proceedings, Warrendale Publishers, Pennsylvania, Vol. 663.

Hayakawa, I. and Kamizono, H. (1993) Durability of an $\mathrm{La}_{2} \mathrm{Zr}_{2} \mathrm{O}_{7}$ waste form in water. Journal of Materials Science, 28, 513-517.

Hodgson, N.A. and Le Bas, M.J. (1992) The geochemistry and cryptic zonation of pyrochlore from San Vicente, Cape Verde Islands. Mineralogical Magazine, 56, 201-214.

Hogarth, D.D. (1977) Classification and nomenclature of the pyrochlore group. American Mineralogist, 62, 403-410.

Hogarth, D.D. (1989) Pyrochlore, apatite and amphibole: distinctive minerals in carbonatite. Pp. 105-141 in: Carbonatites: Genesis and Evolution (K. Bell, editor). Unwin Hyman, London.

Hogarth, D.D. and Horne, J.E.T. (1989) Non-metamictic uranoan pyrochlore and uranpyroclore from tuff near Ndale, Fort Portal area, Uganda. Mineralogical Magazine, 53, 257-262.

Johan, V. and Johan, Z. (1994) Accessory minerals in the Cínovec (Zinnwald) granite cupola, Czech Republic. Part 1: Nb-, Ta- and Ti-bearing oxides. Mineralogy and Petrology, 51, 323-343.

Laurenzi, M.A. and Villa, I.M. (1985) K/Ar chronology of the Vico Volcano (Latium, Italy). IAVCEI, 1985 Scientific Assembly, Giardini Naxos, Italy, Abstract Volume.

Locardi, E. (1965) Tipi di ignimbriti di magmi mediterranei. Il vulcano di Vico. Atti Società Toscana di Scienze Naturali, 45, 55-173.
Lower, S.K., Maurice, P.A. and Traina, S.J. (1998a) Simultaneous dissolution of hydroxyapatite and precipitation of hydroxypyromorphite: direct evidence of homogeneous nucleation. Geochimica and Cosmochimica Acta, 62, 1773-1780.

Lower, S.K., Maurice, P.A., Traina, S.J. and Carlson, E.H. (1998b) Aqueous Pb sorption by hydroxylapatite: applications of atomic force microscopy to dissolution, nucleation and growth studies. American Mineralogist, 83, 147-158.

Lumpkin, G.R. and Ewing, R.C. (1988) Alpha-decay damage in minerals of the pyrochlore group. Physics and Chemistry of Minerals, 16, 2-20.

Lumpkin, G.R. and Ewing, R.C. (1992) Geochemical alteration of pyrochlore group minerals: Microlite subgroup. American Mineralogist, 77, 179-188.

Lumpkin, G.R. and Ewing, R.C. (1996) Geochemical alteration of pyrochlore group minerals: Betafite subgroup. American Mineralogist, 81, 1237-1248.

Lumpkin, G.R., Hart, K.P., McGlinn, P.J., Payne, T.E., Gieré, R. and Williams, C.T. (1994) Retention of actinides in natural pyrochlores and zirconolites. Radiochimica Acta, 66/67, 469-474.

Lumpkin, G.R., Day, R.A., McGlinn, P.J., Payne, T.E., Gieré, R. and Williams, C.T. (1999) Investigation of the long-term performance of betafite and zirconolite in hydrothermal veins from Adamello, Italy. Pp. 793-800 in: Scientific Basis for Nuclear Waste Management XXII (D.J. Wronkiewicz and J.H. Lee, editors) Materials Research Society Symposium Proceedings, Warrendale Publishers, Pennsylvania, Vol. 556.

Lumpkin, G.R., Ewing, R.C., Williams, C.T. and Mariano, A.N. (2001) An overview of the crystal chemistry, durability, and radiation damage effects of pyrochlore from natural systems. Pp. 921-934 in: Scientific Basis for Nuclear Waste Management XXIV (K.P. Hart and G.R. Lumpkin, editors). Materials Research Society Symposium Proceedings, Warrendale Publishers, Pennsylvania, Vol. 663.

Mazzi, F. and Munno, R. (1983) Calciobetafite (new mineral of the pyrochlore group) and related minerals from Campi Flegrei, Italy; crystal structures of polymingite and zirkelite: comparison with pyrochlore and zirconolite. American Mineralogist, 68, 262-276.

Oberti, R., Ottolini, L., Cámara, F. and Della Ventura, G. (1999) Crystal structure of non-metamict Th-rich hellandite-(Ce) from Latium (Italy) and crystal chemistry of the hellandite-group minerals. American Mineralogist, 84, 913-921.

Oberti, R., Ottolini, L., Della Ventura, G. and Parodi, G.C. (2001) On the symmetry and crystal chemistry of britholite: new structural and microanalytical data. American Mineralogist, 86, 1066-1075. 


\section{F. CÁMARA ET AL.}

Ohnenstetter, D. and Piantone, P. (1992) Pyrochloregroup minerals in the Beauvoir peraluminous leucogranite, Massif Central, France. The Canadian Mineralogist, 30, 771-784.

Petruk, W. and Owens, D.R. (1975) Electron microprobe analyses for pyrochlores from Oka, Quebec. The Canadian Mineralogist, 13, 282-285.

Potts, P.J., Tindle, A.G. and Isaacs, M.C. (1983) On the precision of electron microprobe data: a new test for the homogeneity of mineral standards. American Mineralogist, 68, 1237-1242.

Pozharitskaya, L.K. and Samoylov, V.S. (1972) Petrologiya, Mineralogiya $i$ Geokhimiya Karbonatitov Vostochnoi Sibiri (L.M. Salikov, editor). Nauka, Moscow. (in Russian) cited in Hogarth, D.D. (1989) Pyrochlore, apatite and amphibole: distinctive minerals in carbonatite. Pp. 105-141 in: Carbonatites: Genesis and Evolution (K. Bell, editor). Unwin Hyman, London.

Ringwood, A.E., Kesson, S.E., Reeve, K.D., Levins, D.M. and Ramm, E.J. (1988) Synrock. Pp. 233-334 in: Radioactive Waste Form for the Future (W. Lutze and R.C. Ewing, editors). North-Holland, Amsterdam.

Robinson, K., Gibbs, G.V. and Ribbe, P.H. (1971) Quadratic elongation: A quantitative measure of distortion in coordination polyhedra. Science, 172, $567-570$.

Shannon, R.D. (1976) Revised effective ionic radii and systematic studies of interatomic distances in halides and chalcogenides. Acta Crystallographica, A32, $751-767$.

Sheldrick, G.M. (1996) SADABS, Siemens area detector absorption correction software. University of Goettingen, Germany.

Sheldrick, G.M. (1997) SHELX-97. Programs for
Crystal Structure Determination and Refinement. University of Goettingen, Germany.

Sollevanti, F. (1983) Geologic, volcanologic and tectonic setting of the Vico-Cimino area, Italy. Journal of Volcanology and Geothermal Research, 17, 203-217.

Speer, J.A. (1982) The actinide orthosilicates. Pp. 113-135 in: Orthosilicates (P.H. Ribbe, editor). Reviews in Mineralogy, 5. The Mineralogical Society of America, Washington, D.C.

Subramanian, M.A., Aravamudan, G. and Subba Rao, G.V. (1983) Oxide pyrochlores - a review. Progress in Solid State Chemistry, 15, 55-143.

Williams, C.T. (1996a) Analysis of rare earth minerals. Pp. 327-348 in: Rare Earth Minerals: Chemistry, Origin and Ore Deposits (A.P. Jones, F. Wall and C.T. Williams, editors). Mineralogical Society Series 7, Chapman \& Hall, London.

Williams, C.T. (1996b) A note on the occurrence of niobian zirconolite, pyrochlore and baddeleyite from the Kovdor carbonatite complex, Kola Peninsula, Russia. Mineralogical Magazine, 60, 639-646.

Wills, A.S. and Brown, I.D. (1999) VaList, CEA, France.

Wise, M.A. and Černý, P. (1990) Primary compositional range and alteration trends of microlite from the Yellowknife pegmatite field, Northwest Territories, Canada. Mineralogy and Petrology, 43, 83-98.

Wu, C., Yuan, Z. and Bai, G. (1996) Rare earth deposits in China. Pp. 281-310 in Rare Earth Minerals. Chemistry, Origin and Ore Deposits (A.P. Jones, F. Wall and C.T. Williams, editors). The Mineralogical Society Series, 7. Chapman \& Hall, London.

[Manuscript received 11 May 2004:

revised 1 October 2004] 